\title{
Trending Research Topics in the Field of Physics Education from 2017 to 2019 in Highly Reputable International Journals
}

\author{
Hartono Bancong ${ }^{1 *}$, Nurazmi ${ }^{2}$, Tri Hastiti Fiskawarni ${ }^{3}$, Jisun Park ${ }^{4}$ \\ 1, 2, 3 Physics Education Department, Universitas Muhammadiyah Makassar, Makassar, 90221, Indonesia \\ ${ }^{4}$ Elementary Education Department, Ewha Womans University, Seoul, 03760, Republic of Korea
}

*Corresponding address: hartono.b.b@unismuh.ac.id

\begin{tabular}{|c|c|}
\hline Article Info & 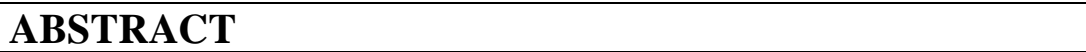 \\
\hline Article history: & $\begin{array}{l}\text { This study aims to map the physics education research topics trending in the } \\
\text { last three years in highly reputable international journals. This is a descriptive }\end{array}$ \\
\hline $\begin{array}{l}\text { Received: February } 14^{\text {th }}, 2021 \\
\text { Accepted: April } 20^{\text {th }}, 2021\end{array}$ & $\begin{array}{l}\text { study that analyzed } 511 \text { articles using content analysis. All articles were } \\
\text { selected from the top } 3 \text { academic journals: International Journal of Science }\end{array}$ \\
\hline Published: April $30^{\text {th }}, 2021$ & Education (IJSE), Research in Science Education (RISE), and Science \\
\hline Keywords: & \\
\hline $\begin{array}{l}\text { Journal; } \\
\text { Physics education; } \\
\text { Research topics; } \\
\text { Trend topics. }\end{array}$ & $\begin{array}{l}\text { science learning: contexts, characteristics, and interactions with a percentage } \\
\text { of } 15.05 \% \text {. Likewise, in the RISE journal, the topics of science learning: } \\
\text { contexts, characteristics, and interactions also ranked first with a percentage } \\
\text { of } 16.30 \% \text {. Meanwhile, the top research topics in the SE journal were } \\
\text { STEM/STEAM, with a percentage of } 13.28 \% \text {. Based on the results, it can be } \\
\text { concluded that overall, the top three research topics highlighted by physics } \\
\text { researchers in highly reputable international journals from } 2017 \text { to } 2019 \\
\text { period were science learning: contexts, characteristics and interactions, } \\
\text { STEM/STEAM, and curriculum and assessment. }\end{array}$ \\
\hline
\end{tabular}

(C) 2021 Physics Education Department, UIN Raden Intan Lampung, Indonesia.

\section{INTRODUCTION}

In the academic world, the publication is an essential activity for researchers. The publication aims to disseminate knowledge to the public and improve the academic careers of researchers, such as positions, funding, or achievement awards (Ackerman et al., 2018; Cavas, 2015; Heffernan, 2020; Kyvik, 2013). Therefore, it is essential for all researchers and practitioners to publish their research results, especially in reputable international journals indexed by credible indexers such as Web of Science (SSCI, SCIE) and Scopus (Bucher, 2018; Chou et al., 2013; Huh, 2017; Liu et al., 2015). Through publication in reputable international journals, researchers and their research results can be widely recognized in their academic community (Beltrán \& Nieto,
2018; Chang et al., 2010; Erduran et al., 2015; Page, 2020).

The community of physics educators often views publication in reputable journals as an essential task because the articles in these journals are of high quality in terms of research methodology and results (Henderson \& Dancy, 2009; Im, 2005; Jho, 2018; Lee \& Kim, 2018). In addition, the publications in reputable journals serve as channels for communicating with other researchers to encourage the development of a more established research field (Lee \& Kim, 2018; Otero \& Meltzer, 2017; Yun, 2020).

Research on physics education makes a real contribution to physics education in secondary schools as a guideline not only for revising the curriculum, which is the 
framework for secondary physics education but also for improving the physics teaching and learning process (Bancong \& Song, 2018; Chusni \& Zakwandi, 2018; Jamali et al., 2015; Meltzer \& Otero, 2015; Yusuf \& Bancong, 2015). Likewise, at the university level, physics education research is used to develop teaching models and strategies to help university students study physics more effectively (Bancong \& Song, 2020; Lee \& Kim, 2018; Thompson et al., 2011). This can make a real contribution to improving the competence of physicists and teachers in the future.

However, several studies have shown that writing for scientific publications is challenging for most academics (Ackerman et al., 2018; Beltrán \& Nieto, 2018; Otero \& Meltzer, 2017; Safitri et al., 2013). Many scholars have difficulty identifying research topics to generate innovative ideas in designing current research. In particular, early researchers have a limited understanding of the characteristics of reputable international journals and research topics that are trending in the field (Beltrán \& Nieto, 2018; Henson, 2009; Jho, 2018; Lee \& Kim, 2018). It is not easy for novice researchers to determine developing research topics, design research, propose hypotheses, write research results, and choose quality journals (Jamali et al., 2015; Lin et al., 2019; Otero \& Meltzer, 2017). Therefore, especially for novice researchers, it is essential to know the research trends in the past, present, and future. This understanding will help to see the field of study from a broader perspective.

So far, more attention has been paid to bibliometric and scientometric approaches to visualizing the research trends in physics education (e.g., Chang et al., 2010; Jamali et al., 2015; Lancho-Barrantes \& Cantú-Ortiz, 2019; Lin et al., 2019). However, no research explicitly describes physics education research topics trending in the last three years (2017-2019). Therefore, this study aims to describe the research topics of physics education trending in highly reputable international journals. Thus, the research questions in this study were as follows:

Regarding physics education research published in 3 highly reputable international journals in the last three years (2017-2019),

1. which research topics are covered, and how are their frequencies distributed?

2. What are the trending research topics?

\section{METHODS}

This is a descriptive study that reviews physics articles published in highly reputable international journals. Data collection and analysis were carried out from April to September 2020. According to Jho (2018), the most relevant sources in physics education research are International Journal of Science Education (IJSE), American Journal of Physics (AJP), Research in Science Education (RISE), European Journal of Physics (EJP), Science Education (SE) and Physical Review Special Topics - Physics Education Research (PRST-PER). These journals are published by credible publishers and indexed in reputable international databases recognized by the Ministry of research, technology, and higher education, Republic of Indonesia. These reputed international journals are indexed by the Web of Science (WoS) and Scopus.

However, after we reviewed all of these journals, we chose three journals as the data source: IJSE, RISE, and SE. The reason for selecting these three journals is because they are the leading journals that have high impact factors and have SJR above 0.8 , and are in the Q1 quartile of the Scimago journal and country rank data. We did not choose AJP, EJP, and PRST-PER because apart from having SJR below 0.8 and being in the Q2 quartile, the number of physics education articles published was not sufficient. These three journals post topics in the field of physics education and issues in the field of physics and astronomy. The flow chart of the research method can be seen in Figure 1. 


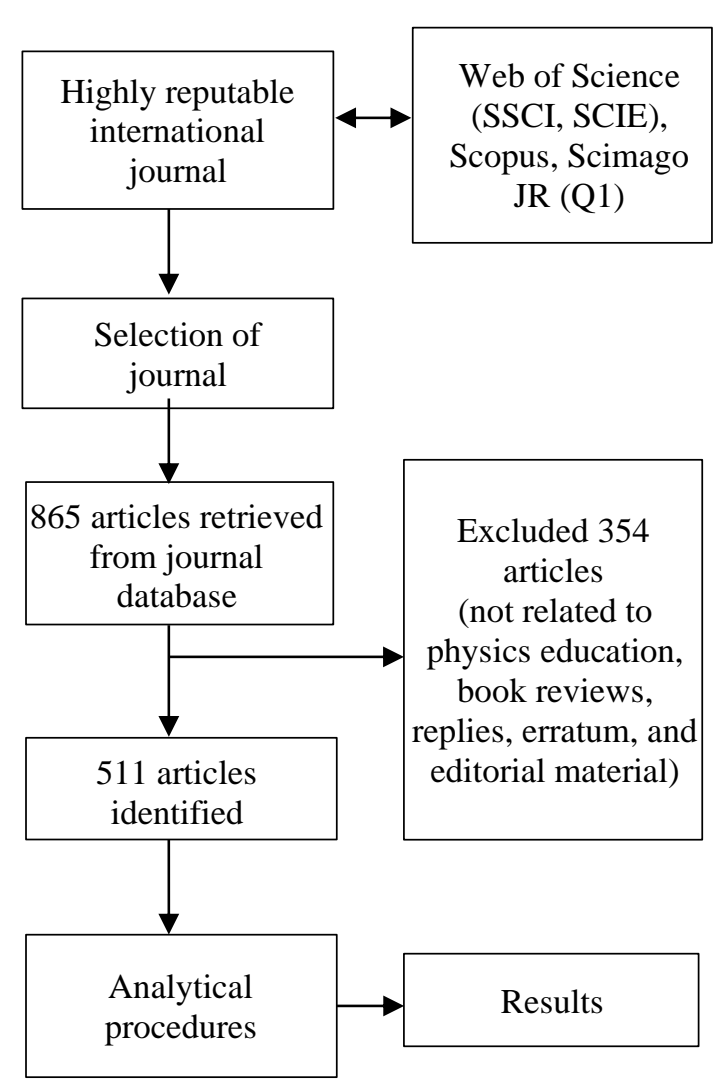

Figure 1. A Flowchart of the Research

Although the three selected journals published general science education articles (physics, chemistry, biology, and earth science education), we only analyzed articles in the field of physics education. The total number of articles in the three selected journals from 2017 to 2019 was 865 . We then excluded articles not related to physics education research. Book reviews, replies, erratum, and editorial material were also excluded because we were only interested in investigating the original research contributions. As a result, the total number of articles analyzed in this study was 511. All of these articles are in the field of physics education. The characteristics of the journals that were the sources of data in this study are presented in Table 1.

To analyze the data, 17 science education research topics were used, which became a reference for physics researchers worldwide as a framework. The 17 research topics were obtained based on research topics at the 2019 National Association for Research in Science Teaching (NARST) Conference and the 2019 European Science Education Research Association (ESERA) Conference. The 17 research topics referred to were (1) science learning: development of student understanding; (2) science learning: contexts, characteristics, and interactions; (3) science teaching: primary, middle, and high school; (4) college science teaching and learning; (5) science learning in informal contexts; (6) pre-service science teacher education; (7) inservice science teacher education; (8) curriculum and assessment; (9) cultural, social, and gender issues; (10) technology for teaching, learning, and research; (11) history, philosophy, sociology, and nature of science; (12) policy, reform, and program evaluation; (13) discourse and argumentation in science education; (14) scientific literacy and socioscientific issues; (15) environmental education and sustainability; (16) STEM / STEAM; (17), etc. (religious beliefs, methodological issues, textbook).

Table 1. The Characteristics of the International Journal as the Source of Data

\begin{tabular}{clccccc}
\hline No. & Journal name & SJR & Quartile & H-Index & Publisher & URL \\
\hline 1 & $\begin{array}{l}\text { International Journal of } \\
\text { Science Education }\end{array}$ & 1,02 & Q1 & 102 & $\begin{array}{l}\text { Taylor \& } \\
\text { Francis }\end{array}$ & $\begin{array}{l}\text { https://www.tandfonline.co } \\
\text { m/toc/tsed20/current }\end{array}$ \\
\hline 2 & $\begin{array}{l}\text { Research in Science } \\
\text { Education }\end{array}$ & 0,89 & Q1 & 50 & Springer & $\begin{array}{l}\text { https://www.springer.com/j } \\
\text { ournal/11165 }\end{array}$ \\
\hline 3 & Science Education & 2,05 & Q1 & 108 & $\begin{array}{l}\text { John Wiley } \\
\text { \& Sons Inc. }\end{array}$ & $\begin{array}{l}\text { https://onlinelibrary.wiley.c } \\
\text { om/journal/1098237x }\end{array}$ \\
\hline
\end{tabular}




\section{RESULTS AND DISCUSSION}

The results of this study represent the topics of physics education research that are trending in the journals IJSE, RISE, and SE as a representation of highly reputable international journals from 2017 to 2019 . As we can see in Table 2, the top topics of physics education research in the IJSE journal are science learning: contexts, characteristics, and interactions. There have been 30 articles covering this topic in the last three years. Research topics for physics education that rank second and third in IJSE are STEM/STEAM and curriculum and assessment. Nineteen articles discuss STEM/STEAM education, while the topic of curriculum and evaluation is 18 articles. Inservice science teacher education ranks fourth and is followed by the topic of science teaching: primary school, middle and high school. The number of articles covering these two topics is 16 and 15 articles, respectively.

In the journal RISE, the topic of science learning: contexts, characteristics, and interactions also rank first as a physics education research topic that has been frequently discussed in the last three years. The number of articles that discuss this topic is 30 articles. Then, the research topic of physics education, which ranks second is science teaching: primary school, middle and high school. Eighteen articles are discussing this topic in the 2017-2019 timeframe. The topic of science learning: development of student understanding ranks third and is followed by curriculum and assessment. The number of articles covering these two topics is 14 and 13 articles, respectively.

On the other hand, science learning topics: contexts, characteristics, and interactions only rank second in the journal SE. The top issue of physics education research in the SE journal in the last three years is STEM/STEAM education. Seventeen articles are discussing this topic from 2017 to 2019. Another research topic, such as science learning: development of student understanding, ranks third. Twelve pieces are talking about this topic in the last three years. The subject of cultural, social, and gender issues and discourse and argumentation in science education also ranks third in the SE journal. The number of articles that discuss this topic as much as 12 for each.

Furthermore, research topics for physics education that researchers rarely discuss in the last three years in the IJSE journal are religious beliefs, methodological issues, and textbooks. There are only 3 out of 199 articles that discuss this topic in the 2017 to 2019 period. Another topic rarely addressed by physics education researchers at IJSE is science learning in informal contexts. Only five articles are discussing the topic in the IJSE journal. The topic of science learning in everyday contexts is also the least discussed research topic by physics education researchers in RISE. Only 4 out of 184 articles published on RISE in the 2017-2019 timeframe discuss this topic. The second topic that physics education researchers in RISE rarely address is college science teaching and learning. During the past three years, only five articles were discussing this topic in the RISE journal.

In the SE journal, research topics that researchers rarely discuss are environmental education and sustainability in the last three years. There is only 1 in 128 articles published in SE discussing this topic. Other topics such as religious beliefs, methodological issues, and textbooks and policy, reform, and program evaluation are also rarely discussed by physics education researchers in the SE journal. The number of articles discussing these two topics from 2017 to 2019 is 2 and 3 pieces, respectively. Overall, the percentage of research topics for physics education published on IJSE, RISE, and SE from 2017 to 2019 is presented in Table 2. 
Table 2. Percentage of Physics Education Research Topics Published on IJSE, RISE, and SE from 2017 to 2019

\begin{tabular}{lccccc}
\hline \multicolumn{1}{c}{ Topics } & IJSE & RISE & SE & Total & $\begin{array}{c}\text { Percentage } \\
(\%)\end{array}$ \\
\hline $\begin{array}{l}\text { Science Learning: Development of Student } \\
\text { Understanding }\end{array}$ & 7 & 14 & 12 & 33 & 6,46 \\
\hline $\begin{array}{l}\text { Science Learning: Contexts, Characteristics, } \\
\text { and Interactions }\end{array}$ & 30 & 30 & 14 & 74 & 14,48 \\
\hline $\begin{array}{l}\text { Science Teaching: Primary School, Middle } \\
\text { and High School }\end{array}$ & 15 & 18 & 5 & 38 & 7,44 \\
\hline College Science Teaching and Learning & 11 & 5 & 4 & 20 & 3,91 \\
\hline Science Learning in Informal Contexts & 5 & 4 & 7 & 16 & 3,13 \\
\hline Pre-service Science Teacher Education & 10 & 11 & 5 & 26 & 5,09 \\
\hline In-service Science Teacher Education & 16 & 11 & 9 & 36 & 7,05 \\
\hline Curriculum and Assessment & 18 & 13 & 10 & 41 & 8,02 \\
\hline Cultural, Social, and Gender Issues & 13 & 11 & 12 & 36 & 7,05 \\
\hline $\begin{array}{l}\text { Technology for Teaching, Learning, and } \\
\text { Research }\end{array}$ & 9 & 9 & 5 & 23 & 4,50 \\
\hline $\begin{array}{l}\text { History, Philosophy, Sociology, and Nature of } \\
\text { Science }\end{array}$ & 8 & 9 & 6 & 23 & 4,50 \\
\hline Policy, Reform, and Program Evaluation & 9 & 7 & 3 & 19 & 3,72 \\
\hline $\begin{array}{l}\text { Discourse and Argumentation in Science } \\
\text { Education }\end{array}$ & 12 & 10 & 12 & 34 & 6,65 \\
\hline Scientific Literacy and Socio-scientific Issues & 7 & 7 & 4 & 18 & 3,52 \\
\hline Environmental Education and Sustainability & 7 & 7 & 1 & 15 & 2,94 \\
\hline STEM/STEAM & 19 & 10 & 17 & 46 & 9,00 \\
\hline $\begin{array}{l}\text { Etc. (Religious Beliefs, Methodological } \\
\text { Issues, Textbook) }\end{array}$ & 3 & 8 & 2 & 13 & 2,54 \\
\hline Total & 199 & 184 & 128 & 511 & 100 \\
\hline
\end{tabular}

Science Learning: Development of Student. .

Science Learning: Contexts, Characteristics and.. Science Teaching: Primary School, Middle and High. College Science Teaching and Learning Science Learning in Informal Contexts Pre-service Science Teacher Education In-service Science Teacher Education Curriculum and Assessment Cultural, Social, and Gender Issues Technology for Teaching, Learning, and Research History, Philosophy, Sociology, and Nature of Science Policy, Reform, and Program Evaluation Discourse and Argumentation in Science Education Scientific Literacy and Socio-scientific Issues Environmental Education and Sustainability STEM/STEAM

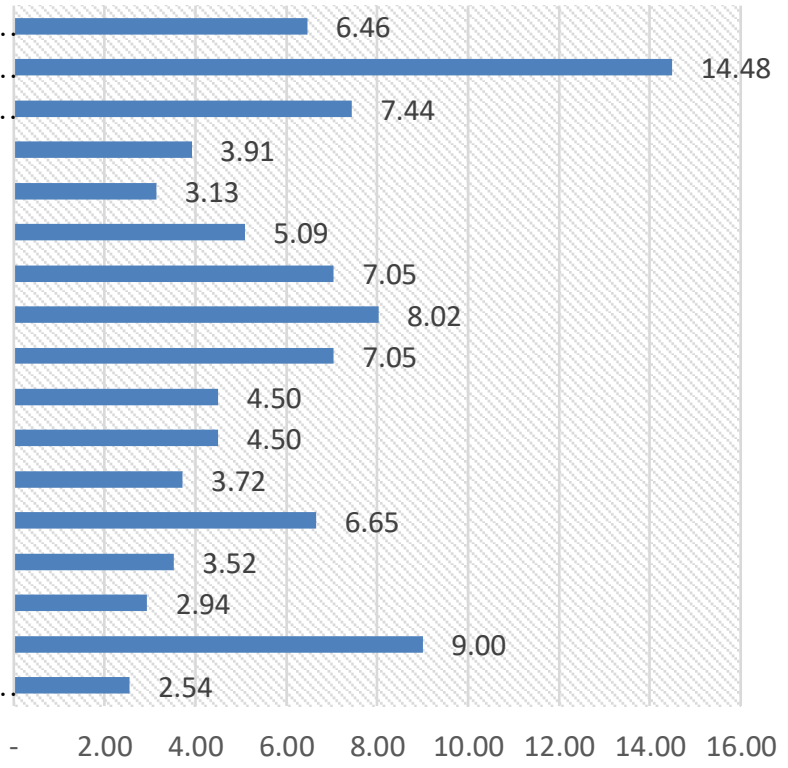

Etc (Religious Beliefs, Methodological Issues,

Figure 2. The Total Percentage of Research Topics for Physics Education Published in Highly Reputable International Journals from 2017 to 2019 
Furthermore, figure 2 shows the total percentage of research topics for physics education published in the journals of IJSE, RISE, and SE as representations of highly reputable international journals from 2017 to 2019. As can be seen, research topics that were the most discussed in the journals of IJSE, RISE, and SE for the last three years are science learning: contexts, characteristics, and interactions. Overall, the percentage of articles that discussed this topic was $14.48 \%$. The second topic that is trending discussed in reputable international journals is STEM/STEAM. There are $9.00 \%$ of articles published on IJSE, RISE, and SE debating this topic. The topic of curriculum and assessment ranks third. The percentage of articles that discuss this topic from 2017 to 2019 is $8.02 \%$. As a trending research topic in reputable international journals in the last three years, the fourth position is science teaching: primary schools, middle and high schools. $7.44 \%$ of articles published in the journals of IJSE, RISE, and SE emphasize this topic. The fifth position is in-service science teacher education and cultural, social, and gender issues. The percentage of articles that discuss these two topics is $7.05 \%$ in each.

In the case of Indonesia, there are no researchers who intensively map the trends in physics education research in recent years. In the previous study, Chusni and Zakwandi (2018) analyzed thesis topics trending in Indonesia's 2013-2017 period. The results showed that the topic of the learning model was a research topic that was trending in the period 2013 - 2017. There were about $69.87 \%$ of the theses they analyzed discussing this topic. Conversely, a research topic rarely addressed by physics education researchers in Indonesia is the learning evaluation. Only $4.56 \%$ of the theses they analyzed discussed this topic. If we compare it to research topics that are trending in reputable international journals, science teaching, which includes learning models, is also one of the trending topics discussed by physics education researchers around the world. As we can see in Figure 2, the topic of science teaching: primary schools, middle and high schools rank fourth as the top physics education research topic in journals of international reputation. Likewise, curriculum and assessment rank third as a trending research topic in reputable international journals. This is different from the study of Chusni and Zakwandi (2018), which claims that the topic of learning evaluation is part of the curriculum and assessment that researchers rarely discuss in Indonesia.

Another research conducted by Faisal et al. (2020) revealed that scientific literacy is a research topic that is trending in Indonesia from 2014 to 2018. According to them, many learning models in Indonesia are directed to increasing students' scientific literacy. Furthermore, Faisal et al. (2020) argued that the topic of scientific literacy had attracted the attention of many researchers in Indonesia because Indonesian students have not performed well in science both on National exams and International comparative assessments, such as PISA and TIMSS. However, when we compared it to trending research topics in reputable international journals, scientific literacy is a topic that physics education researchers rarely discuss at this time. As seen in Figure 2 , the percentage of articles that discuss the issues of scientific literacy and socioscientific issues is only $3.52 \%$.

Thus, the results of this study are expected to become a reference for researchers, especially physics education, in determining research topics to generate innovative ideas in designing current research. Research topics such as science learning: contexts, characteristics, and interactions, STEM/STEAM, and curriculum and assessment are expected to be topics that will be studied by researchers in physics education in Indonesia. These topics are being heavily studied in reputable international journals. 


\section{CONCLUSION AND SUGGESTION}

Based on the results, it can be concluded that the research topics of physics education that are trending from 2017 to 2019 in the journal of IJSE, RISE, and SE as a representation of highly reputable international journals are science learning: contexts, characteristics, and interactions $(14,48 \%)$, STEM/STEAM $(9,00 \%)$ and curriculum and assessment (8,02\%). Shortly, these three research topics will likely continue to be hot topics to be pursued by physics education researchers from around the world. Conversely, the research topics of environmental education and sustainability, and religious beliefs, methodological issues, textbooks are two topics that physics education researchers rarely discuss in highly reputable international journals in the last three years.

For future researchers, it is necessary to research trends in physics education research topics in Indonesia. This aims to map research topics and find out how far the research topics of physics education in Indonesia are in line with trending research topics in highly reputable international journals.

\section{ACKNOWLEDGMENT}

This work was funded by the Institute for Research, Development, and Community Service, the Muhammadiyah University of Makassar, through the University Internal Grant under the contract number: 0011/Kontr-Panel/Pengabd/IV/1441/2020.

\section{REFERENCES}

Ackerman, E., Hunter, J., \& Wilkinson, Z. T. (2018). The availability and effectiveness of research supports for early career academic librarians. The Journal of Academic Librarianship, 44(5), 553-568.

Bancong, H., \& Song, J. (2018). Do physics textbooks present the ideas of thought experiments?: A case in Indonesia. Jurnal Pendidikan IPA Indonesia, 7(1), 25-33.

Bancong, H., \& Song, J. (2020). Exploring how students construct collaborative thought experiments during physics problem-solving activities. Science and Education, 29(3), 617-645. https://doi.org/10.1007/s11191-02000129-3

Beltrán, M. L. C., \& Nieto, M. C. (2018). Challenges in sustaining a peripheral journal. Profile: Issues in Teachers' Professional Development, 20(2), 9-14.

Bucher, S. (2018). Bibliometric analysis of central European journals in the web of science and JCR social science edition. Malaysian Journal of Library \& Information Science, 23(2), 95-110.

Cavas, B. (2015). Research trends in science education international: A content analysis for the last five years (20112015). Science Education International, 26(4), 573-588.

Chang, Y.-H., Chang, C.-Y., \& Tseng, Y.-H. (2010). Trends of science education research: An automatic content analysis. Journal of Science Education and Technology, 19(4), 315-331.

Chou, C. P., Lin, H. F., \& Chiu, Y. (2013). The impact of SSCI and SCI on Taiwan's academy: An outcry for fair play. Asia Pacific Education Review, 14(1), 23-31.

Chusni, M. M., \& Zakwandi, R. (2018). Trend analysis of physics prospective teachers' research: An effort to improve the academic quality of physics study program. Jurnal Ilmiah Pendidikan Fisika Al-BiRuNi, 7(1), 11-19.

Erduran, S., Ozdem, Y., \& Park, J.-Y. (2015). Research trends on argumentation in science education: A journal content analysis from 1998-2014. International Journal of STEM Education, 2(1), 1-12.

Faisal, F., Gi, G. M., \& Martin, S. N. (2020). Analysis of government-funded research in indonesia from 2014-2018: Implications for research trends in science education. Jurnal Pendidikan IPA Indonesia, 9(2), 146-158.

Heffernan, T. (2020). Academic networks and career trajectory: There's no career in academia without networks. Higher 
Education Research \& Development, 114.doi: 10.1080/07294360.2020.1799948

Henderson, C., \& Dancy, M. H. (2009). Impact of physics education research on the teaching of introductory quantitative physics in the United States. Physical Review Special Topics-Physics Education Research, 5(2), 20107.120107.9.

Henson, K. T. (2009). Writing for publication: A shift in perspective. Phi Delta Kappan, 90(10), 776a - 776.

Huh, S. (2017). How to successfully list a journal in the social science citation index or science citation index expanded. Korean Journal of Medical Education, 29(4), 221.

Im, S.-M. (2005). Trends and significance of research about beliefs in physics education and cultural approaches. Journal of the Korean Association for Science Education, 25(3), 371-381.

Jamali, S. M., Md Zain, A. N., Samsudin, M. A., \& Ale Ebrahim, N. (2015). Publication trends in physics education: A bibliometric study. Journal of Educational Research, 35, 19-36.

Jho, H. (2018). The past and the present of physics education at a glance: A review of international studies on physics education by using science mapping tool. New Physics: Sae Mulli, 68(10), 1096-1106.

Kyvik, S. (2013). The academic researcher role: Enhancing expectations and improved performance. Higher Education, 65(4), 525-538.

Lancho-Barrantes, B. S., \& Cantú-Ortiz, F. J. (2019). Science in Mexico: A bibliometric analysis. Scientometrics, 118(2), 499-517.

Lee, B., \& Kim, H. (2018). Trends of the research in physics education in Korea. Journal of the Korean Physical Society, 72(12), 1502-1507.

Lin, T.-J., Lin, T.-C., Potvin, P., \& Tsai, C.-C. (2019). Research trends in science education from 2013 to 2017: A systematic content analysis of publications in selected journals. International Journal of Science Education, 41(3), 367-387.

Liu, W., Hu, G., Tang, L., \& Wang, Y. (2015). China's global growth in social science research: Uncovering evidence from bibliometric analyses of SSCI publications (1978-2013). Journal of Informetrics, 9(3), 555-569.

Meltzer, D. E., \& Otero, V. K. (2015). A brief history of physics education in the United States. American Journal of Physics, 83(5), 447-458.

Otero, V. K., \& Meltzer, D. E. (2017). The past and future of physics education reform. Physics Today, 70(5), 50-56.

Page, D. (2020). The academic as consumed and consumer. Journal of Education Policy, 35(5), 585-601.

Safitri, I. K., Bancong, H., \& Husain, H. (2013). Pengaruh pendekatan multiple intelligences melalui model pembelajaran langsung terhadap sikap dan hasil belajar kimia peserta didik di SMA Negeri I Tellu Limpoe. Jurnal Pendidikan IPA Indonesia, 2(2), 156-160.

Thompson, J. R., Christensen, W. M., \& Wittmann, M. C. (2011). Preparing future teachers to anticipate student difficulties in physics in a graduate-level course in physics, pedagogy, and education research. Physical Review Special TopicsPhysics Education Research, 7(1), 10108.1-10108.11.

Yun, E. (2020). Review of trends in physics education research using topic modeling. Journal of Baltic Science Education, 19(3), 388-400.

Yusuf, I., \& Bancong, H. (2015). Implemantasi pembelajaran kurikulum 2013 berbasis multimedia interaktif pada pokok bahasan listrik magnet terhadap aktivitas, persepsi, dan hasil belajar peserta didik di SMA Tut Wuri Handayani Makassar. Jurnal Fisika Indonesia, 18(53), 62-65. 